\title{
Variability of individuals from a population Varronia curassavica Jacq. considering volatile compounds
}

\section{Thaíse Ohana Moura Fernandes ${ }^{1^{*}}$ Emanuelle Oliveira Araújo ${ }^{1}$ Adson Pereira dos Santos $^{2} \mathbb{D}$ Júlio Cesar Rodrigues Lopes Silva ${ }^{3}$ Francine Souza Alves da Fonseca ${ }^{1}$ (D) Alcinei Místico Azevedo ${ }^{1}$ (D) Ernane Ronie Martins ${ }^{1}$ (D)}

'Instituto de Ciências Agrárias, Universidade Federal de Minas Gerais (UFMG), 39404-547, Montes Claros, MG, Brasil. E-mail: thaiseohana@hotmail.com. *Corresponding author.

${ }^{2}$ Departamento de Engenharia Agrícola, Universidade Federal de Viçosa (UFV), Viçosa, MG, Brasil.

${ }^{3}$ Faculdade de Ciências Agronômicas, Universidade Estadual Paulista Júlio de Mesquita Filho (UNESP), Botucatu, SP, Brasil.

ABSTRACT: Varronia curassavica is a medicinal species native to Brazil; its anti-inflammatory properties are attributed to $\alpha$-humulene and $\beta$-caryophyllene. This study to investigated the population variability of V. curassavica. Leaves were collected from 40 individuals of a natural population and transferred to glass flasks $(2 \mathrm{~mL})$. The volatiles were extracted and analyzed using static headspace gas chromatography coupled with mass spectrometry (HS-GC-MS). A total of 17 compounds were detected: monoterpenes (1.6\% - 68\%) and sesquiterpenes $(25.7 \%-79.0 \%)$, including $\alpha$-humulene and $\beta$-caryophyllene. Multivariate analysis was performed to estimate the dissimilarity of individuals separated the compounds into four groups. Group I was characterized by the content of $\alpha$-pinene, groups II and IV by $\beta$-caryophyllene, and group III by $\beta$-pinene. The abundance of $\alpha$-humulene showed small variations; while $\beta$-caryophyllene showed larger variations that contributed to the population variability. This is the first report on the chemical composition analysis of volatile compounds in $V$. curassavica using the $H S-G C-M S$ technique.

Key words: $\alpha$-humulene, $\beta$-caryophyllene, Boraginaceae, Cordia verbenacea D.C., genetic resources.

Variabilidade de indivíduos de uma população de Varonia curassavica Jacq. a partir de compostos voláteis

RESUMO: Varronia curassavica é uma espécie medicinal nativa no Brasil e sua propriedade anti-inflamatória é atribuida aos compostos $\alpha$-humuleno e $\beta$-cariofileno. O objetivo foi estudar a variabilidade de população de V. curassavica. Foram coletadas folhas de 40 indivíduos de população natural, sendo estas transferidas para frascos de vidro $(2 \mathrm{~mL})$. Os voláteis foram extraídos e analisados por headspace estático, associado à cromatografia gasosa, acoplada à espectrometria de massas (HS-CG-EM). Detectou-se 17 compostos: monoterpenos (1,6\% - 68\%) e sesquiterpenos $(25,7 \%$ - 79,0\%), incluindo o $\alpha$-humuleno e o $\beta$-cariofileno. A análise multivariada foi realizada para estimar a dissimilaridade dos indivíduos, a qual separou quatro grupos. O grupo I foi caracterizado pela presença do $\alpha$-pineno, os grupos II e IV do $\beta$-cariofileno e o grupo III do $\beta$-pineno. O teor do $\alpha$-humuleno apresentou pequenas variações, enquanto o do $\beta$-cariofileno contribuiu mais para a variabilidade da população. É o primeiro relato de análise da composição química de compostos voláteis de V. curassavica utilizando a técnica $H S-G C-M S$.

Palavras-chave: $\alpha$-humuleno, $\beta$-cariofileno, Boraginaceae, Cordia verbenacea DC., recursos genéticos.

\section{INTRODUCTION}

The essential oil destilled from the leaves of Varronia curassavica Jacq. has commercial value in the pharmaceutical industry because it contains $\alpha$-humulene and $\beta$-caryophyllene as chemical markers, enabling the development of a genuinely Brazilian herbal medicine (RYAN, 2010). The plant belongs to Boraginaceae (borage family) (SOUZA \& LORENZI, 2012) and is popularly known as "Erva-baleeira". The plant reaches 1.5 to $2.0 \mathrm{~m}$ in height, has simple, aromatic, and alternating leaves, and small white flowers (LORENZI \& MATOS, 2002). It is native to Brazil where it has a wide distribution (INCT, 2020) including in "Vale do Jequitinhonha" and North of Minas Gerais (MENDES et al., 2015).

Volatile compounds, including essential oils present in medicinal and aromatic plants, can be studied as an alternative to identify chemical markers of the species (RICHTER \& SCHELLENBERG, 2007). These molecules are

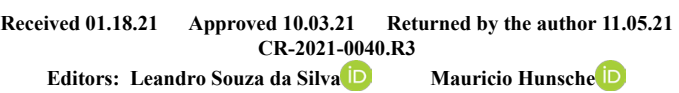


essential for validating some medicinal plants for reliable and safe use (BESSA et al., 2013). Also, diversity in the chemical composition of a plant's natural population can be an important indicator of the existing genetic variability, affecting the quality of the feedstock obtained from extraction.

Decree No. 5.813, from June 22, 2006, that established the National Policy on Medicinal Plants and Herbal Medicines (BRAZIL, 2006) provides guidelines to ensure safe access to the population and the rational use of herbal medicines and medicinal plants in Brazil, promoting sustainability and the development of production chain and of industries including pharmaceutical, medical, and food industries. It is essential to determine the chemical composition of plants to guarantee safety and quality reproducibility. Health professionals can feel safer when recommending herbal medicines if there is a standardization of plant extracts based on levels of active compounds or appropriate chemical markers (SOUZA-MOREIRA et al., 2010).

Research involving medicinal plants is multidisciplinary; it covers the food, pharmaceutical, cosmetic, medicinal, zootechnical, and veterinary fields. Plant-derived compounds have been shown to have potential therapeutic uses, so is essential investing in these products in addition to research with conventional drugs (MOHAMMADHOSSEINI et al., 2019). Industries and consumers are interested in using products of plant origin as alternatives to chemically synthesized products; therefore, research on the development of herbal drugs is necessary (MOHAMMADHOSSEINI, 2017).

Research has demonstrated therapeutic properties of genera such as Achillea, Ziziphora, and Ferula linked to the phytochemicals present in these medicinal plants (MOHAMMADHOSSEINI et al., 2017a; MOHAMMADHOSSEINI, 2017; MOHAMMADHOSSEINI et al., 2019). Most of the studies on the isolation, characterization, and biological activity of medicinal plant compounds are from the Middle East and a few European countries and these studies are mainly "in vitro" (MOHAMMADHOSSEINI, 2017; MOHAMMADHOSSEINI et al., 2017a). Studies of "in vivo" and clinical trials should be carried out to complement such investigations, establish the therapeutic use of these plants, and determine side effects and mechanisms of action (MOHAMMADHOSSEINI, 2017; MOHAMMADHOSSEINI et al., 2017a). It is also important to understand further aspects of the species such as biology and phytochemistry, discover new properties, and prove those already reported by ethnobotany (MOHAMMADHOSSEINI et al., 2017a). Although, chemical variations in a medicinal species are not of much interest to the pharmaceutical industry and the production of herbal medicines, variability is important for the conservation and improvement of the species; to maintain the conservation of the species, variability must be preserved, and their management must be adequate (KAHILAINEN et al., 2014). The loss of variability can decrease plants' capacity for evolution due to environmental changes and can contribute to the extinction of species (FRANKHAM, 2003). Thus, assessing variability among plants of the same species is important for their management (HOELTGEBAUM et al., 2015).

There are published studies on the chemical composition of essential oils and volatile compounds using traditional (hydrodistillation) and advanced (headspace and solvent-free microwave) techniques from medicinal plant species with phytotherapeutic potential (MOHAMMADHOSSEINI et al., 2017b; NEKOEI \& MOHAMMADHOSSEINI, 2016; NEKOEI \& MOHAMMADHOSSEINI, 2016; ZANOUSI et al., 2016). The headspace technique is simple, fast, cheap, uses little plant material, requires little or no preparation of the sample, involves little energy expenditure, and requires no solvents. However, most compounds detected by various techniques were similar: oxygenated monoterpenes, monoterpene hydrocarbons, oxygenated sesquiterpenes, sesquiterpene hydrocarbons, and non-terpene hydrocarbons were found to be common to all techniques (ZANOUSI et al., 2016).

The headspace technique is suitable for the identification of sesquiterpene hydrocarbons (NEKOEI \& MOHAMMADHOSSEINI, 2017) including $\alpha$-humulene and $\beta$-caryophyllene that are chemical markers of $V$. curassavica, justifying the use of these technique for this species. Using the headspace technique, 108 compounds were detected while the hydrodistillation technique detected 68 compounds, and the solvent-free microwave extraction detected 70 (ZANOUSI et al., 2016). The static headspace technique coupled to mass spectrometry (HS-GCMS) can be used to analyze volatiles efficiently and is quick, easy, and reproducible (CANUTI et al., 2009); it extracts, separates, and detects important volatile compounds in the analyzed sample without interference from solvents (UBEDA et al., 2011). This study assessed the chemical variability (volatile compounds) of $V$. curassavica Jacq. population using the static headspace technique. 


\section{MATERIALS AND METHODS}

The leaves of Varronia curassavica (Jacq.) Boraginaceae (MCCA 954) (INCT, 2020) were collected from 40 individuals of a natural adult population in the district of São Gonçalo do Rio das Pedras, a rural area of the municipality of Serro, in the "Vale do Jequitinhonha", Minas Gerais, Brazil. The individuals' geographic coordinates (Figure 1) were determined using the Global Positioning System (GPS) receiver, Garmin GPSMap 60s portable, used in the construction of the location map.

Leaf samples (1 g) from each individual, separated by at least $5 \mathrm{~m}$ from each other on the field, were collected in the second half of 2015. The leaves were immediately transferred to a glass headspace flask $(20 \mathrm{~mL})$ and maintained at $-5{ }^{\circ} \mathrm{C}$ until analysis.

The flasks containing the leaves were transferred to an automatic sampler (HS combiPAL), homogenized (500 rpm), incubated at 75 ${ }^{\circ} \mathrm{C}$ for $5 \mathrm{~min}$, and the injection volume $(1000 \mu \mathrm{L})$ was removed using a preheated syringe $\left(75{ }^{\circ} \mathrm{C}\right)$ (AGUIAR et al., 2014). The Agilent Technologies system (7890A) coupled to the mass spectrometer (MS 5975C) equipped with fused silica capillary column DB-5 MS (30 m x $0.25 \mathrm{~mm} \times 0.25 \mu \mathrm{m})$ and supplied with helium (flow $1 \mathrm{~mL} \cdot \mathrm{min}$ - 1 ) as carrier gas was used for the separation and identification of compounds. The temperature was programmed from $60{ }^{\circ} \mathrm{C}$ to $240{ }^{\circ} \mathrm{C}$ with an increase of $3{ }^{\circ} \mathrm{C} \mathrm{min}-1$. The system was operated in scan mode $\left(2.89 \mathrm{scan} \mathrm{s}^{-1}\right)$ with an electronic impact at $70 \mathrm{eV}$, in the range of 45 to $550(\mathrm{~m} / \mathrm{z})$ (ADAMS, 2012).

The relative abundance (\%) of each compound was determined from the total ion chromatogram and organized according to the order of elution. Identification of the compounds was performed by comparing the mass spectrum to the National Institute of Standards and Technology (NIST, 2009), the calculated relative retention index (IR) (VAN DEN DOOL \& KRATZ, 1963), and the specialized literature (ADAMS, 2012).

A multivariate analysis was performed using the Genes software (CRUZ, 2013) to evaluate the dissimilarity of individuals. The Tocher optimization grouping method (CRUZ et al., 2014) was used based on Euclidean distance, and the Singh method (1981) was applied to the most important compouns when determining the compounds' dissimilarity.

\section{RESULTS AND DISCUSSION}

Seventeen compounds (Tables 1, 2, 3, 4) were detected and identified in the leaves of $V$. curassavica Jacq. highlighting monoterpenes (1.6\% - $68.1 \%)$ and sesquiterpenes $(25.7 \%$ - $79 \%)$. The two chemical markers of the species, $\beta$-caryophyllene

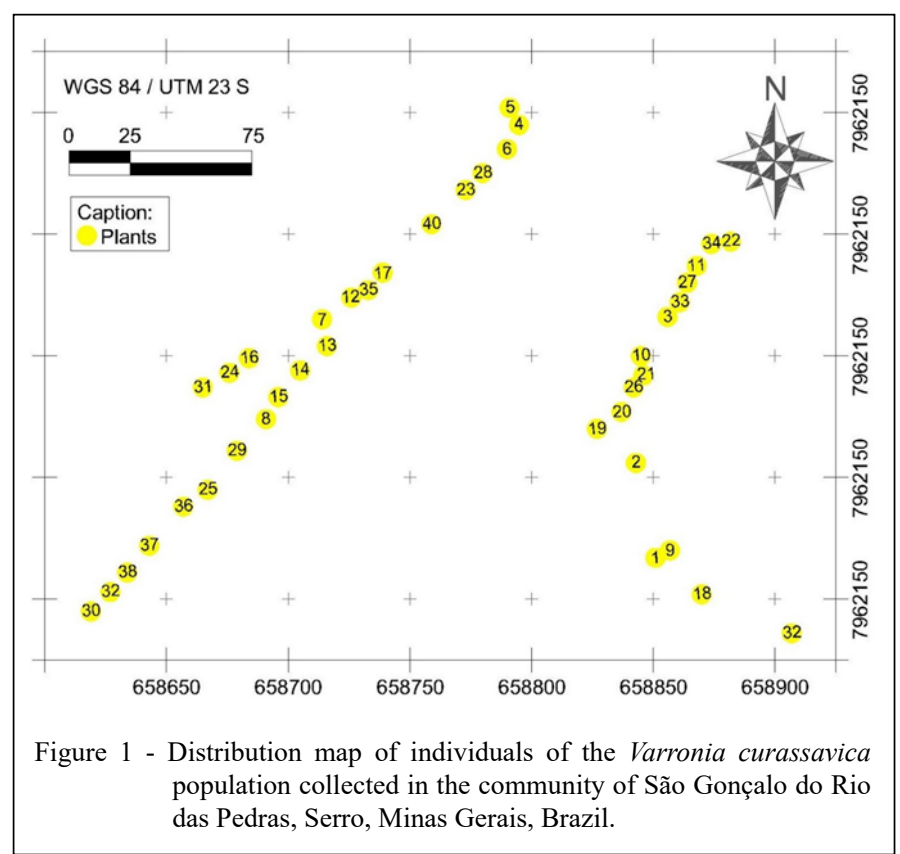

Ciência Rural, v.52, n.8, 2022. 
Table 1 - Volatile compounds analyzed by HS-GC-MS from the leaves of Varronia curassavica Jacq. population collected in São Gonçalo do Rio das Pedras, municipality of Serro, Minas Gerais, Brazil.

\begin{tabular}{|c|c|c|c|c|c|c|c|c|c|c|c|c|}
\hline & & & 1 & 2 & 3 & 4 & 5 & 6 & 7 & 8 & 9 & 10 \\
\hline RT & $\mathrm{RI}_{\mathrm{tab}}$ & Compounds & \multicolumn{10}{|c|}{ 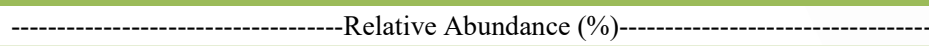 } \\
\hline 9.2 & 846 & Hex-2-enal & - & - & - & - & - & - & 2.2 & - & - & - \\
\hline 14.1 & 932 & $\alpha$-Pinene & 43.2 & 43.4 & 35.8 & 5.6 & 4.6 & 35.3 & 1.5 & 22.1 & 7.9 & 18.7 \\
\hline 14.7 & 946 & Camphene & - & - & - & - & - & - & - & - & 2.4 & - \\
\hline 16.9 & 974 & $\beta$-Pinene & 19.5 & 15.1 & 24.3 & 22.7 & 15.3 & 11.9 & 2.8 & 13.1 & 26.5 & 19.6 \\
\hline 17.7 & 988 & $\beta$-Myrcene & 2.4 & 2.0 & 3.1 & 1.8 & - & - & 3.1 & - & 16.7 & 2.6 \\
\hline 20.2 & 1025 & Sylvestrene & 1.1 & 1.1 & 1.4 & 1.2 & - & - & - & - & 2.1 & 1.2 \\
\hline 20.4 & 1026 & Eucalyptol & - & - & - & - & - & - & 3.0 & - & 1.8 & - \\
\hline 21.5 & 1032 & $\beta$-Cimene & - & - & - & - & 1.3 & - & - & - & - & - \\
\hline 38.0 & 1374 & Copaene & 2.6 & 2.8 & 2.1 & 4.8 & - & - & 4.3 & 2.8 & 2.2 & 3.0 \\
\hline 38.3 & 1387 & $\beta$-Bourbonene & - & - & - & 1.9 & 5.3 & 3.2 & 2.8 & - & - & - \\
\hline 38.5 & 1389 & $\beta$-Elemene & 1.1 & - & - & 1.8 & 1.4 & 1.1 & 2.2 & - & - & 1.8 \\
\hline 39.3 & 1409 & $\alpha$-Gurjunene & - & 1.0 & 1.0 & - & - & - & 2.0 & - & - & - \\
\hline 39.6 & 1417 & $\beta$-Caryophyllene & 8.9 & 10.5 & 12.1 & 22.7 & 24.1 & 19.7 & 30.9 & 17.3 & 12.1 & 20.2 \\
\hline 40.7 & 1452 & $\alpha$-Humulene & 1.0 & 1.2 & 1.4 & 2.5 & 2.8 & 2.1 & 3.5 & 2.0 & 1.3 & 2.2 \\
\hline 40.9 & 1458 & Alloaromadendrene & 2.6 & 3.3 & 2.3 & - & - & 3.5 & 5.6 & - & 2.0 & 2.9 \\
\hline 41.7 & 1513 & $\gamma$-Cadinene & 9.4 & 8.6 & 7.2 & 17.5 & 23.9 & 12.9 & 15.0 & 11.9 & 9.6 & 11.7 \\
\hline 42.1 & 1559 & Germacrene B & 2.3 & 3.6 & 3.2 & 2.9 & 5.7 & - & - & 5.7 & 2.0 & 3.5 \\
\hline \multicolumn{2}{|c|}{ Others $^{*}$} & & 5.9 & 7.5 & 6.1 & 14.6 & 14.2 & 10.2 & 21.1 & 20.5 & 13.6 & 12.8 \\
\hline \multicolumn{2}{|c|}{ Monoterpenes } & & 66.2 & 61.5 & 64.6 & 31.3 & 21.2 & 47.3 & 7.5 & 35.2 & 55.5 & 42.0 \\
\hline \multicolumn{2}{|c|}{ Sesquiterpernes } & & 27.8 & 30.9 & 29.2 & 54.1 & 63.3 & 42.5 & 66.3 & 39.7 & 29.2 & 45.3 \\
\hline \multicolumn{2}{|c|}{ Total } & & 94.0 & 92.5 & 93.9 & 85.4 & 84.5 & 89.8 & 78.9 & 74.9 & 86.4 & 87.2 \\
\hline
\end{tabular}

${ }^{*}$ Compounds below $1 \%$ of the chromatographic peak area. (-): Compounds not detected. RItab: tabulated retention index (ADAMS, 2012). RT: retention time (minutes). The numbers 1 to 10 correspond to the individuals selected for the study. HS-GC-MS: static headspace chromatography coupled with mass spectrometry.

(8.9 - 37.3\%) and $\alpha$-humulene $(1.0 \%-3.8 \%)$ were among the latter (CARVALHO JÚNIOR et al., 2004). These molecules are responsible for the antiinflammatory action of this plant (PASSOS et al., 2007; FERNANDES et al., 2007).

$\beta$-Caryophyllene and $\alpha$-humulene were detected in the volatiles of all analyzed samples, except for sample 31 in which $\beta$-caryophyllene was not detected. $\beta$-Pinene $(1.6 \%-30.8 \%)$ and $\gamma$-cadinene $(1.2 \%-23.9 \%)$ were also detected in the leaf volatiles of all analyzed individuals. In a study by RODRIGUES et al. (2012), essential oils of "ervabaleeira" contained $\alpha$-pinene, $\beta$-pinene, $\beta$-elemene, $\beta$-myrcene, $\beta$-caryophyllene, $\alpha$-humulene, and $\gamma$-cadinene. QUEIROZ et al. (2016) also analyzed the essential oil of "erva-baleeira" leaves and detected monoterpenes (15.2\%) such as $\alpha$-pinene, $\beta$-pinene, and sesquiterpenes $(62.3 \%)$ such as $\beta$-caryophyllene and $\alpha$-humulene. The chemical composition of essential oils from the leaves of "erva-baleeira" analyzed in our study was similar to the volatiles detected in leaves by Rodrigues et al. (2012) and QUEIROZ et al. (2016).

The published literature shows that the HS-GC-MS technique is an important methodology in qualitative chemical analysis and is being evaluated for new applications (SNOW \& BULLOCK, 2010). CANUTI et al. (2009) reported that the same compounds detected as volatiles during ripening of grapes were also present in the wine produced using the same grapes. In a study by LEBRUN et al. (2008), it was observed that the analysis of mango volatile compounds defined the ideal maturity of the fruits for harvesting in a non-destructive way. The HS-GC-MS technique was efficient in detecting main hydrocarbons when evaluating volatile compounds in red algae (ALENCAR et al., 2017). In a study with Trigonella elliptica, the static headspace technique efficiently detected volatile compounds that were also detected 
Table 2 - Volatile compounds analyzed by HS-GC-MS from the leaves of Varronia curassavica Jacq. population collected in São Gonçalo do Rio das Pedras, municipality of Serro, Minas Gerais, Brazil.

\begin{tabular}{|c|c|c|c|c|c|c|c|c|c|c|c|c|}
\hline & & & 11 & 12 & 13 & 14 & 15 & 16 & 17 & 18 & 19 & 20 \\
\hline RT & $\mathrm{RI}_{\mathrm{tab}}$ & Compounds & \multicolumn{10}{|c|}{ 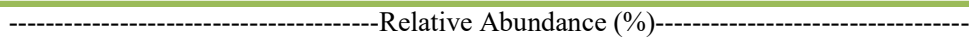 } \\
\hline 9.2 & 846 & Hex-2-enal & - & - & - & - & - & - & - & - & - & - \\
\hline 14.1 & 932 & $\alpha$-Pinene & 5.7 & 48.9 & - & 22.3 & 29.1 & 8.3 & 4.0 & 22.9 & - & 27.5 \\
\hline 14.7 & 946 & Camphene & - & - & - & - & - & 1.0 & - & - & - & - \\
\hline 16.9 & 974 & $\beta$-Pinene & 23.1 & 16.3 & 13.9 & 20.2 & 23.3 & 29.0 & 11.9 & 15.9 & 1.6 & 13.4 \\
\hline 17.7 & 988 & $\beta$-Myrcene & 1.1 & 1.9 & 2.0 & 2.7 & 3.1 & 3.5 & - & 2.1 & - & 1.1 \\
\hline 20.2 & 1025 & Sylvestrene & 1.1 & 1.1 & 1.0 & 1.3 & 1.4 & 1.4 & - & - & - & - \\
\hline 20.4 & 1026 & Eucalyptol & - & - & - & - & - & - & - & - & - & - \\
\hline 21.5 & 1032 & $\beta$-Ocimene & - & - & - & - & - & - & - & - & - & - \\
\hline 38.0 & 1374 & Copaene & 4.8 & 1.9 & 2.5 & 3.2 & 2.8 & 3.4 & 2.9 & 3.2 & 5.4 & 3.5 \\
\hline 38.3 & 1387 & $\beta$-Bourbonene & 1.7 & 1.3 & - & - & - & 1.3 & - & 1.0 & 1.2 & - \\
\hline 38.5 & 1389 & $\beta$-Elemene & 1.3 & - & - & - & 1.4 & - & 2.0 & - & 1.3 & - \\
\hline 39.3 & 1409 & $\alpha$-Gurjunene & - & - & - & - & - & - & - & - & - & - \\
\hline 39.6 & 1417 & $\beta$-Caryophyllene & 19.3 & 11.1 & 13.0 & 18.6 & 10.3 & 16.8 & 29.5 & 18.3 & 37.3 & 20.9 \\
\hline 40.7 & 1452 & $\alpha$-Humulene & 2.3 & 1.2 & 1.4 & 2.0 & 1.2 & 2.0 & 3.1 & 1.9 & 3.8 & 2.2 \\
\hline 40.9 & 1458 & Alloaromadendrene & 3.4 & 2.0 & - & - & - & - & 2.3 & - & - & - \\
\hline 41.7 & 1513 & $\gamma$-Cadinene & 19.9 & 6.1 & 10.0 & 12.2 & 11.0 & 15.8 & 12.2 & 11.8 & 24.2 & 11.2 \\
\hline 42.1 & 1559 & Germacrene B & 2.5 & 2.1 & 4.5 & 2.8 & 4.3 & 4.9 & 6.3 & 3.7 & 5.8 & 2.9 \\
\hline \multicolumn{2}{|c|}{ Others ${ }^{*}$} & & 13.8 & 6.2 & 48.6 & 14.6 & 12.2 & 12.7 & 19.8 & 14.9 & 9.2 & 14.1 \\
\hline \multicolumn{2}{|c|}{ Monoterpenes } & & 31.0 & 68.1 & 16.8 & 46.5 & 56.9 & 43.2 & 16.0 & 40.9 & 1.6 & 42.0 \\
\hline \multicolumn{2}{|c|}{ Sesquiterpernes } & & 55.2 & 25.7 & 31.4 & 38.9 & 31.0 & 44.2 & 58.2 & 39.9 & 79.0 & 40.7 \\
\hline \multicolumn{2}{|l|}{ Total } & & 86.2 & 93.8 & 48.2 & 85.4 & 87.8 & 87.3 & 74.1 & 80.8 & 80.5 & 82.7 \\
\hline
\end{tabular}

*Compounds below $1 \%$ of the chromatographic peak area. (-): Compounds not detected. RItab: tabulated retention index (ADAMS, 2012). RT: retention time (minutes). The numbers 11 to 20 correspond to the individuals selected for the study. HS-GC-MS: static headspace chromatography coupled with mass spectrometry.

by GC-MS and GC-FID analysis of essential oils (BAHMANZADEGAN et al., 2017).

The HS-GC-MS technique was also efficient in detecting volatile compounds and the main marker compounds in the leaves, flowers, and stems of Elsholtzia ciliate medicinal plant; it even detected differences in plant composition between parts of the plant (WANG et al., 2017). HE et al. (2019) considered the technique to be simple, fast, and precise for analyzing volatile compounds of Clausena lansium and suggested that it should be used for the quality control of plants, foods, and herbal medicines. The effectiveness, repeatability, and reliability of the technique allow it to be used efficiently to determine the chemical profile of foods because the volatile compounds detected by the technique represent the food composition (LIBERTO et al., 2019). Although, essential oils are different in many aspects from volatile compounds, the literature supports the notion that it is possible to predict the chemical compounds present in essential oils from the chemical composition of volatile compounds in the leaves of medicinal plants.

It is also possible to predict plant metabolites using the headspace technique, even with a small number of leaves. This technique is faster and cheaper compared to the essential oil analyses as it does not require a massive volume of leaves for oil extraction, thus simplifying the analysis process.

Table 5 shows the groups of similar volatile compounds extracted from the leaves of $V$. curassavica. Four groups were formed by the Tocher method, three with one individual each: group II (individual 5), group III (individual 9), and group IV (individual 7). The remaining individuals corresponding to $92.5 \%$ of the total formed Group I.

$\beta$-caryophyllene was the most abundant in groups II and IV, while $\alpha$-pinene was the most abundant in group I and $\beta$-pinene in group III. Groups II and IV were considered distinct even with $\beta$-caryophyllene as the major compound; this may have occurred due to the number of compounds 
Table 3 - Volatile compounds analyzed by HS-GC-MS from the leaves of Varronia curassavica Jacq. population collected in São Gonçalo do Rio das Pedras, municipality of Serro, Minas Gerais, Brazil.

\begin{tabular}{|c|c|c|c|c|c|c|c|c|c|c|c|c|}
\hline & & & 21 & 22 & 23 & 24 & 25 & 26 & 27 & 28 & 29 & 30 \\
\hline RT & $\mathrm{RI}_{\mathrm{tab}}$ & Compounds & \multicolumn{10}{|c|}{------------------------------------Relative Abundance (\%)--------------------------------' } \\
\hline 9.2 & 846 & Hex-2-enal & 1.0 & - & - & - & - & - & - & - & - & - \\
\hline 14.1 & 932 & $\alpha$-Pinene & 4.5 & - & 30.8 & 5.6 & 31.8 & 22.3 & 5.8 & 9.0 & 10.9 & 43.3 \\
\hline 14.7 & 946 & Camphene & - & - & - & - & - & - & - & 1.0 & - & - \\
\hline 16.9 & 974 & $\beta$-Pinene & 19.2 & 12.8 & 16.0 & 22.7 & 15.8 & 20.7 & 25.0 & 34.2 & 3.6 & 14.2 \\
\hline 17.7 & 988 & $\beta$-Myrcene & 1.5 & 1.6 & 1.3 & 2.9 & 1.1 & 2.8 & 3.2 & 4.3 & - & 2.0 \\
\hline 20.2 & 1025 & Sylvestrene & - & - & - & 1.1 & - & 1.2 & 1.4 & 1.9 & - & 1.0 \\
\hline 20.4 & 1026 & Eucalyptol & - & - & - & - & - & - & - & - & - & - \\
\hline 21.5 & 1032 & $\beta$-Ocimene & - & - & - & - & - & - & - & - & - & - \\
\hline 38.0 & 1374 & Copaene & 4.7 & 2.8 & 3.4 & 3.8 & 1.6 & 2.1 & 4.6 & 3.6 & 3.9 & 2.7 \\
\hline 38.3 & 1387 & $\beta$-Bourbonene & - & - & - & - & - & - & - & - & - & - \\
\hline 38.5 & 1389 & $\beta$-Elemene & 2.2 & 1.0 & - & 1.2 & 2.3 & 1.1 & 1.2 & - & 1.0 & - \\
\hline 39.3 & 1409 & $\alpha$-Gurjunene & - & - & - & 1.0 & - & - & - & - & - & - \\
\hline 39.6 & 1417 & $\beta$-Caryophyllene & 19.8 & 19.3 & 16.3 & 19.5 & 12.8 & 17.3 & 16.2 & 12.7 & 30.1 & 14.1 \\
\hline 40.7 & 1452 & $\alpha$-Humulene & 2.3 & 2.0 & 1.8 & 2.2 & 1.5 & 1.8 & 1.9 & 1.4 & 3.0 & 1.5 \\
\hline 40.9 & 1458 & Alloaromadendrene & - & 2.1 & - & 3.9 & 2.0 & 2.4 & - & - & 2.6 & - \\
\hline 41.7 & 1513 & $\gamma$-Cadinene & 20.3 & 10.1 & 13.9 & 17.1 & 7.6 & 10.0 & 17.8 & 13.8 & 15.1 & 10.3 \\
\hline 42.1 & 1559 & Germacrene B & 9.4 & 4.0 & 2.6 & 5.1 & 3.2 & & 7.3 & 4.5 & 3.9 & 3.1 \\
\hline \multicolumn{2}{|c|}{ Others* } & & 13.1 & 40.6 & 13.9 & 13.9 & 20.4 & 16.0 & 14.6 & 13.4 & 20.8 & 7.9 \\
\hline \multicolumn{2}{|c|}{ Monoterpenes } & & 25.2 & 14.5 & 48.1 & 32.3 & 48.6 & 46.8 & 35.4 & 50.5 & 14.5 & 60.4 \\
\hline \multicolumn{2}{|c|}{ Sesquiterpernes } & & 58.7 & 41.2 & 38.1 & 53.8 & 31.0 & 34.8 & 49.0 & 36.1 & 59.8 & 31.7 \\
\hline \multicolumn{2}{|c|}{ Total } & & 84.9 & 55.7 & 86.1 & 86.1 & 79.6 & 81.6 & 84.4 & 86.6 & 74.2 & 92.1 \\
\hline
\end{tabular}

"Compounds below $1 \%$ of the chromatographic peak area. (-): Compounds not detected. RItab: tabulated retention index (ADAMS, 2012). RT: retention time (minutes). The numbers 21 to 30 correspond to the individuals selected for the study. HS-GC-MS: static headspace chromatography coupled with mass spectrometry.

detected in group IV that were not detected in group II and the proportion of $\gamma$-cadinene that was higher in group II (23.9\%) than in group IV $(9.6 \%)$.

Camphene and sylvestrene $(1.0-2.1 \%)$ were detected in groups I and III. $\beta$-Ocimene was detected in group II. Hex-2-enal was detected in groups I and IV. $\beta$-myrcene $(1.1-16.7 \%)$, copaene $(1.6-5.4 \%)$, $\alpha$-gurjunene $(1.0-17.4 \%)$, and alloaromadendrene (2.0 $-7.6 \%$ ) appeared in groups I, III, and IV. Eucalyptol (1.8 $-3,0 \%$ ) was detected in groups III and IV. $\beta$-Burbonene $(1.0-5.3 \%)$ and $\beta$-elemene $(1.0-2.7 \%)$ were detected in groups I, II, and IV, and germacrene B (2.0 - 9.4\%) was detected in groups I, II, and III.

Variations in volatile compounds can be attributed to genetic and environmental factors such as altitude, temperature, and luminosity, in addition to the phenological stage. However, as the observation area was only 4.41 ha with an altitude variation of only 18 $\mathrm{m}$, without variations observed in the occurring soil and with the plants in bloom, the observed chemical variability is probably due to genetic differences.
According to FIGUEIREDO et al. (2008), there are internal and external factors that interfere with the production of volatile and essential oil compounds in plants such as the stage of development of the plant organs, temperature, and light. However, temperature and light may not explain the variations observed in our study since the individuals were close to each other. It should be noted that this species is a facultative allogamous species (BRANDÃO et al., 2015); therefore, there is genetic variability between individuals.

$V$. curassavica is a resilient species in terms of genetics, as it is a polyploid with selfincompatibility that provides greater conservation of the species' genetic diversity and contributes to the chemical variations presented by the species. Matrices have a greater number of private alleles (exclusive to a population) than descendants, indicating that individuals from a population do not participate in the same way in the reproductive process and may present variability among themselves. The chemical variation may also have occurred because of the 
Table 4 - Volatile compounds analyzed by HS-GC-MS from the leaves of Varronia curassavica Jacq. population collected in São Gonçalo do Rio das Pedras, municipality of Serro, Minas Gerais, Brazil.

\begin{tabular}{|c|c|c|c|c|c|c|c|c|c|c|c|c|}
\hline & & & 31 & 32 & 33 & 34 & 35 & 36 & 37 & 38 & 39 & 40 \\
\hline RT & $\mathrm{RI}_{\mathrm{tab}}$ & Compounds & \multicolumn{10}{|c|}{--- } \\
\hline 9.2 & 846 & Hex-2-enal & - & - & - & - & - & - & - & - & - & 1.4 \\
\hline 14.1 & 932 & $\alpha$-Pinene & 32.3 & 7.9 & 15.8 & 17.8 & 27.6 & 5.3 & 4.4 & 1.7 & 3.1 & 8.7 \\
\hline 14.7 & 946 & Camphene & - & - & - & - & - & - & - & - & - & - \\
\hline 16.9 & 974 & $\beta$-Pinene & 21.4 & 30.8 & 19.4 & 19.7 & 23.0 & 23.7 & 17.4 & 4.1 & 9.7 & 5.9 \\
\hline 17.7 & 988 & $\beta$-Myrcene & 2.8 & 3.8 & & 1.7 & 3.0 & 1.9 & - & 3.4 & - & - \\
\hline 20.2 & 1025 & Sylvestrene & 1.3 & 1.5 & 1.0 & 1.0 & 1.4 & 1.1 & - & - & - & - \\
\hline 20.4 & 1026 & Eucalyptol & - & - & - & - & - & - & - & - & - & - \\
\hline 21.5 & 1032 & $\beta$-Ocimene & - & - & - & - & - & - & - & - & - & - \\
\hline 38.0 & 1374 & Copaene & 2.1 & - & 4.2 & 4.7 & 2.5 & 4.3 & 3.1 & 3.7 & 4.4 & 4.4 \\
\hline 38.3 & 1387 & $\beta$-Bourbonene & - & - & - & 1.3 & - & 1.4 & - & - & - & - \\
\hline 38.5 & 1389 & $\beta$-Elemene & - & - & - & 1.1 & 1.9 & 1.1 & 1.1 & 2.7 & 1.1 & - \\
\hline 39.3 & 1409 & $\alpha$-Gurjunene & 17.4 & 1.7 & - & - & - & - & - & 1.2 & - & - \\
\hline 39.6 & 1417 & $\beta$-Caryophyllene & - & 24.3 & 15.0 & 12.5 & 13.7 & 21.0 & 27.5 & 31.7 & 29.3 & 25.8 \\
\hline 40.7 & 1452 & $\alpha$-Humulene & 1.7 & 2.5 & 1.7 & 1.6 & 1.4 & 2.3 & 2.8 & 3.2 & 3.0 & 2.7 \\
\hline 40.9 & 1458 & Alloaromadendrene & - & 7.6 & 4.5 & - & 2.4 & - & 3.0 & 2.9 & - & - \\
\hline 41.7 & 1513 & $\gamma$-Cadinene & 9.3 & 1.2 & 14.8 & 18.7 & 9.6 & 16.1 & 11.4 & 13.9 & 18.0 & 17.9 \\
\hline 42.1 & 1559 & Germacrene B & 2.4 & 2.7 & 3.4 & 2.8 & 2.0 & 7.8 & 6.0 & 6.2 & 7.9 & 3.8 \\
\hline \multicolumn{2}{|c|}{ Others ${ }^{*}$} & & 6.3 & 15.9 & 19.0 & 16.2 & 11.6 & 14.0 & 16.6 & 18.0 & 18.4 & 23.7 \\
\hline \multicolumn{2}{|c|}{ Monoterpenes } & & 57.8 & 44.1 & 36.3 & 40.2 & 54.9 & 32.0 & 21.8 & 9.1 & 12.8 & 14.5 \\
\hline \multicolumn{2}{|c|}{ Sesquiterpernes } & & 32.9 & 40.0 & 43.7 & 42.7 & 33.5 & 54.0 & 54.8 & 65.5 & 63.7 & 54.6 \\
\hline \multicolumn{2}{|c|}{ Total } & & 90.7 & 84.1 & 80.0 & 82.9 & 88.4 & 86.0 & 76.6 & 74.6 & 76.4 & 70.6 \\
\hline
\end{tabular}

${ }^{*}$ Compounds below $1 \%$ of the chromatographic peak area. (-): Compounds not detected. RItab: tabulated retention index (ADAMS, 2012). RT: retention time (minutes). The numbers 31 to 40 correspond to the individuals selected for the study. HS-GC-MS: static headspace chromatography coupled with mass spectrometry.

variability from deprived alleles of other populations being present in individuals of the studied population (their descendants) due to cross-pollination (HOELTGEBAUM \& REIS, 2017). The genetic variability expressed in the chemical variation may

Table 5 - Groups formed by Tocher's method in the study of the genetic dissimilarity of individuals from the population of Varronia curassavica Jacq. collected in São Gonçalo do Rio das Pedras, municipality of Serro, Minas Gerais, Brazil.

\begin{tabular}{|c|c|}
\hline Groups & Individuals \\
\hline I & \begin{tabular}{lcccccc}
20 & 23 & 18 & 8 & 30 & 14 & 13 \\
22 & 15 & 10 & 26 & 35 & 3 & 1 \\
2 & 12 & 33 & 34 & 25 & 24 & 37 \\
27 & 36 & 11 & 4 & 16 & 29 & 17 \\
39 & 28 & 38 & 21 & 40 & 6 & 19 \\
\multicolumn{5}{c}{32} & 31 &
\end{tabular} \\
\hline II & 5 \\
\hline III & 9 \\
\hline IV & 7 \\
\hline
\end{tabular}

also have occurred as the individuals are native and have not undergone any domestication process (BRANDÃO et al., 2015).

The compounds that contributed most to the chemical variation of the volatiles in "ervabaleeira" individuals were $\alpha$-pinene, $\beta$-pinene, and $\beta$-caryophyllene, adding up to $86.37 \%$ of the relative contribution; compounds that contributed less were hex-2-enal, camphene, and $\beta$-ocimene, representing $0.11 \%$ (Table 6 ). This variation is related to the relative abundance of compounds in individuals and their absence or presence.

$\alpha$-Humulene contributes little to the divergence among individuals $(0.12 \%)$ as its abundance in the population showed small variations. This is important because a smaller variation in the relative abundance of a compound between individuals could serve for the standardization of the raw material when vegetative propagation is carried out. It can also assist in the conservation of the species. When aiming extractivism, management can become more efficient by 
Table 6 - Relative contribution (SJ\%) of characteristics to the divergence of individuals from the population of Varronia curassavica Jacq. collected in São Gonçalo do Rio das Pedras, municipality of Serro, Minas Gerais, Brazil, estimated by the method proposed by SINGH (1981).

\begin{tabular}{lcc}
\hline Compounds & S.J (\%) \\
\hline$\alpha$-Pinene & 56.02 \\
$\beta$-Pinene & 15.24 \\
$\beta$-Caryophyllene & 15.11 \\
$\gamma$-Cadinene & 6.10 \\
$\alpha$-Gurjunene & 2.05 \\
$\beta$-Myrcene & 1.92 \\
Germacrene B & 1.20 \\
Alloaromadendrene & 0.94 \\
Copaene & 0.45 \\
$\beta$-Bourbonene & 0.34 \\
$\beta$-Elemene & 0.18 \\
$\alpha$-Humulene & 0.12 \\
\hline Sylvestrene & 0.12 \\
\hline Eucalyptol & 0.08 \\
\hline Hex-2-enal & 0.05 \\
\hline Camphene & 0.05 \\
\hline -Ocimene & 0.01 \\
\hline
\end{tabular}

varying the plants in each harvest and by considering their reestablishment at the subsequent harvests. The existing variability can be used in the selection of genotypes with the greatest potential for pharmacological action. Few individuals, only three in forty, differed in chemical composition relative to the population (7.5\%). However, even though few individuals diverge, there can be genetic losses when considering extraction as a source of raw material for the pharmaceutical industry (OLIVEIRA \& ROPKE, 2016).

Figure 2 shows the geographical layout of the groups obtained from geographical coordinates.

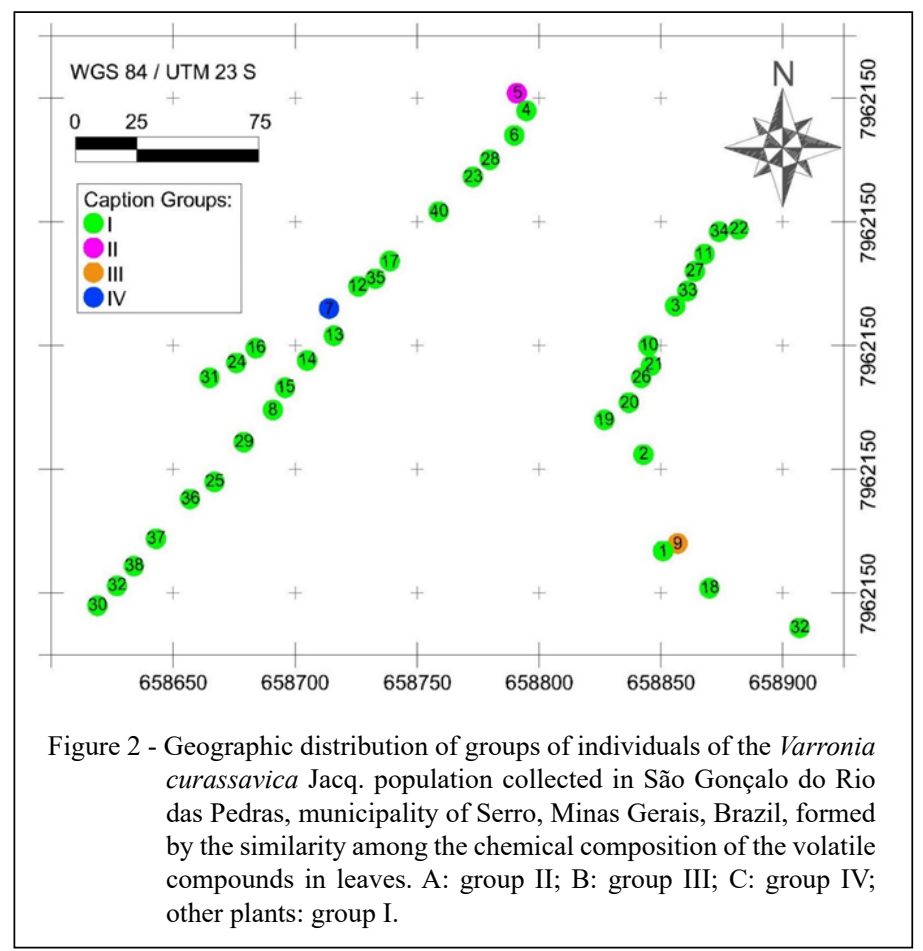

Ciência Rural, v.52, n.8, 2022. 
Groups II, III, and IV were distant from each other, with group I being arranged throughout the area, among the other groups.

The results of the groups formed by the chemical composition match their geographical distribution because the groups that separate themselves (II, III, and IV) were composed of only one individual with greater chemical diversity relative to the rest of the population, which were distant from each other. Group I, had a greater number of individuals with greater chemical similarity, arranged among the other groups.

\section{CONCLUSION}

Varronia curassavica Jacq. population studied the patterns of chemical diversity, and $\beta$-caryophyllene was one of the compounds that contributed the most to this variation. The HSGC-MS technique was efficient for the extraction, separation, and identification of volatiles including the chemical markers of $V$. curassavica. This is the first study to report on the chemical composition analysis of volatile compounds of the species using the HS-GC-MS technique.

\section{DECLARATION OF CONFLICT OF INTEREST}

The authors declare no conflict of interest. The founding sponsors had no role in the design of the study; in the collection, analyses, or interpretation of data; in the writing of the manuscript; and in the decision to publish the results.

\section{ACKNOWLEDGEMENTS}

This study was financed in part by the Coordenação de Aperfeiçoamento de Pessoal de Nível Superior - Brasil (CAPES) Finance Code 001. To the Conselho Nacional de Desenvolvimento Científico e Tecnológico (CNPq), to the Programa de Educação Tutorial (PET) and to the National Institute of Science and Herbal Virtual Technology of Flora and Fungi (INCT-HVFF), which receives financial support from the $\mathrm{CNPq}$.

\section{AUTHORS' CONTRIBUTIONS}

All authors contributed equally for the conception and writing of the manuscript. All authors critically revised the manuscript and approved of the final version.

\section{REFERENCES}

ADAMS, R. P. Identification of essential oils componets by gas chromatography/ mass spectroscopy. Carol Stream: USA, 2012.

AGUIAR, M. C. S. et al. Volatile compounds from fruits of Butia capitata at different stages of maturity and storage. Food research international, v.62, p.1095-1099, 2014. Available from: <https:// doi.org/10.1016/j.foodres.2014.05.039>. Accessed: Jan. 18, 2020. doi: 10.1016/j.foodres.2014.05.039.

ALENCAR, D. B. et al. Chemical composition of volatile compounds in two red seaweeds, Pterocladiella capillacea and Osmundaria obtusiloba, using static headspace gas chromatography mass spectrometry. Journal of Applied Phycology, v.29, n.3, 1571-1576, 2017. Available from: <https://https://doi.org/10.1007/ s10811-016-1020-3>. Accessed: Jan. 20, 2020. doi: 10.1007/ s10811-016-1020-3.

BAHMANZADEGAN, A. et al. Chemical constituents of the essential oil, static headspace analysis of volatile compounds, polyphenolic content and antioxidative capacity of Trigonella elliptica Boiss. grown in Iran. Analytical Chemistry Letters, v.7, n.2, p.261-270, 2017. Available from: < https://www.tandfonline. com/doi/abs/doi.org/10.1080/22297928.2017.1333038>. Accessed: Jan. 18, 2020. doi: 10.1080/22297928.2017.1333038.

BESSA, N. G. F. et al. Prospecção fitoquímica preliminar de plantas nativas do cerrado de uso popular medicinal pela comunidade rural do assentamento vale verde-Tocantins. Revista Brasileira de Plantas Medicinais, v.15, n.4, p.692-707, 2013. Available from: <https://www.scielo.br/scielo.php?pid=S151605722013000500010\&script $=$ sci_arttext $>$. Accessed: Feb. 15, 2020. doi: 10.1590/S1516-05722013000500010.

BRANDÃO, D. S. et al. Flowering phenology and reproductive system of the Cordia (Varronia curassavica Jacq.). Revista Brasileira de Plantas Medicinais, v.17, n.4, p.562-569, 2015. Available from: <https://www.scielo.br/scielo.php?pid=S1516$05722015000400562 \&$ script $=$ sci arttext\&tlng=pt. Accessed: Mar. 31, 2020. doi: 10.1590/1983-084X X/14_011.

BRASIL. 2006. Decreto $\mathbf{n}^{\mathbf{0}} \mathbf{5 . 8 1 3}$, de 22 de junho de 2006, about Política Nacional de Plantas Medicinais e Fitoterápicos, Brasília, Brasil. Available from: <http://www.planalto.gov.br/ccivil_03/ ato2004-2006/2006/decreto/d5813.htm>. Accessed: Jan. 18, 2020

CANUTI, V. et al. Headspace solid-phase microextraction-gas chromatography-mass spectrometry for profiling free volatile compounds in Cabernet Sauvignon grapes and wines. Journal of Chromatography A, v.1216, n.15, p.3012-3022, 2009. Available from: <https://doi.org/10.1016/j.chroma.2009.01.104>. Accessed: Jan. 18, 2020. doi: 10.1016/j.chroma.2009.01.104.

CARVALHO JÚNIOR, P. et al. Chemical composition and antimicrobial activity of the essential oil of Cordia verbenacea DC. Journal of Ethnopharmacology, v.95, p.297-301, 2004. Available from: <https://doi.org/10.1016/j.jep.2004.07.028>. Accessed: Jan. 18, 2020. doi: 10.1016/j.jep.2004.07.028.

CRUZ, C. D. et al. Modelos biométricos aplicados ao melhoramento genético. Viçosa: Editora UFV, 2014. 514p.

CRUZ, C. D. Genes a software package for analysis in experimental statistics and quantitative genetics. Acta Scientiarum. Agronomy, v.35, n.3, p.271-276, 2013. Available from: <https://doi. org/10.4025/actasciagron.v35i3.21251>Accessed: Mar. 11, 2020. doi: 10.4025/actasciagron.v35i3.21251.

FERNANDES, E. S. et al. Anti-inflammatory effects of compounds alpha-humulene and (-)-trans-caryophyllene isolated from the essential oil of Cordia verbenacea. European journal of pharmacology, v.569, n.3, p.228-236, 2007. Available from:

Ciência Rural, v.52, n.8, 2022. 
$<$ https://doi.org/10.1016/j.ejphar.2007.04.059>. Accessed: Jan. 18, 2020. doi: 10.1016/j.ejphar.2007.04.059.

FIGUEIREDO, A. C. et al. Factors affecting secondary metabolite production in plants: volatile components and essential oils. Flavour and Fragrance Journal, v.23, n.4, p.213-226, 2008 Available from: <https://doi.org/10.1002/ffj.1875>. Accessed: Jan. 18, 2020. doi: 10.1002/ffj.1875, 2008 .

FRANKHAM, R. Genetics and conservation biology. Comptes Rendus Biologies, v.326, p.22-29, 2003. Available from: $<\mathrm{https}: / /$ doi.org/10.1016/S1631-0691(03)00023-4>. Accessed: Jan. 18, 2020. doi: 10.1016/S1631-0691(03)00023-4.

$\mathrm{He}, \mathrm{X}$. et al. Rapid and sensitive analysis of Volatile Components of Different Parts of Clausena lansium by Ionic Liquid Based Headspace Gas Chromatography-Mass Spectrometry. Molecules, v.24, n.1, p.91, 2019. Available from: <https:// doi.org/10.3390/ molecules24010091>. Accessed: Feb. 15, 2020. doi: 10.3390/ molecules 24010091 .

HOELTGEBAUM, M. P. et al. Genetic diversity and structure of Varronia curassavica Jacq. populations in the restinga of Santa Catarina Island. Revista Brasileira de Plantas Medicinais, v.17, p.1083-1090, 2015. Available from: <https://www.scielo.br/ scielo.php?pid=S1516-05722015000701083\&script $=$ sci arttext $>$. Accessed: Jan. 18, 2020. doi: 10.1590/1983-084x/14_120.

HOELTGEBAUM, M. P.; REIS, M. S. Genetic diversity and population structure of Varronia curassavica: A medicinal polyploid species in a threatened ecosystem. Journal of Heredity, v.108, n.4, p.415-423, 2017. Available from: <https:// doi.org/10.1093/jhered/esx010>. Accessed: Jan. 18, 2020. doi: 10.1093/jhered/esx010.

INCT - National Institute of Science and Herbal Virtual Technology of Flora and Fungi. Algas, Fungos e Plantas. Available from: $<$ http://inct.splink.org.br/>. Accessed: Apr. 04, 2020.

KAHILAINEN, A. et al. Conservation implications of speciesgenetic diversity correlations. Global Ecology and Conservation, v.2, p.315-323, 2014. Available from: <http://doi.org/10.1016/j. gecco.2014.10.013>. Accessed: Apr. 04, 2020. doi: 10.1016/j. gecco.2014.10.013.

LEBRUN, M. et al. Discrimination of mango fruit maturity by volatiles using the electronic nose and gas chromatography Postharvest Biology and Technology, v.48, n.1, p.122131, 2008. Available from: <http://doi.org/10.1016/j. postharvbio.2007.09.010>. Accessed: Apr. 04, 2020. doi: 10.1016/j.postharvbio.2007.09.010

LIBERTO E. et al. Headspace sampling: An "evergreen" method in constant evolution to characterize food flavors through their volatile fraction, pp. 1-37. In: Food Chemistry, Function and Analysis. Ed. Royal Society of Chemistry, 2019. Available from: $<$ http://doi.org/10.1039/9781788015752-00001>. Accessed: Mar. 14, 2020. doi: $10.1039 / 9781788015752-00001$.

LORENZI, H.; MATOS, F. J. A. Plantas medicinais no Brasil: nativas e exóticas. Nova Odessa: Brasil, 2002.

MENDES, A. D. R. et al. Ecogeografia de populações de ervabaleeira (Varronia curassavica) no Norte e Vale do Jequitinhonha em Minas Gerais. Ciência Rural, v.45, n.3, p.418-424, 2015. Available from: <http://www.scielo.br/scielo.php?pid=S0103- 84782015000300418\&script=sci_arttext $>$. Accessed: Apr. 02, 2020. doi: $10.1590 / 0103-8478 \mathrm{cr} 20140196$.

MOHAMMADHOSSEINI, $\mathrm{M}$ et al. Chemical composition of the essential oils and extracts of Achillea species and their biological activities: Journal of Ethnopharmacology, v.199, p.257-315, 2017a. Available from: <https://doi.org/10.1016/j. jep.2017.02.010>. Accessed: Apr. 06, 2021. doi: 10.1016/j. jep.2017.02.010.

MOHAMMADHOSSEINI, M. et al. Chemical composition of the essential oils from the aerial parts of Artemisia sieberi by using conventional hydrodistillation and microwave assisted hydrodistillation: A comparative study. Journal of essential oil bearing plants, v.19, p.32-45, 2016. Available from: $<$ https://doi. org/10.1080/0972060X.2015.1119067>. Accessed: Apr. 06, 2021. doi: 10.1080/0972060X.2015.1119067.

MOHAMMADHOSSEINI, M. et al. Profiling of Compositions of Essential Oils and Volatiles of Salvia limbata Using Traditional and Advanced Techniques and Evaluation for Biological Activities of Their Extracts. Chemistry \& Biodiversity, v.14, n.5, p.e1600361, 2017b. Available from: $<$ https://doi.org/10.1002/ cbdv.201600361>. Accessed: Apr. 06, 2021. doi: 10.1002/ cbdv.201600361.

MOHAMMADHOSSEINI, M. The ethnobotanical, phytochemical and pharmacological properties and medicinal applications of essential oils and extracts of different Ziziphora species. Industrial Crops and Products, v.105, p.164-192, 2017a. Available from: $<$ https://doi.org/10.1016/j.indcrop.2017.05.009>. Accessed: Apr. 06, 2021. doi: 10.1016/j.indcrop.2017.05.009.

MOHAMMADHOSSEINI, Metal. The genus Ferula: Ethnobotany, phytochemistry and bioactivities-A review. Industrial Crops and Products, v.129, p.350-394, 2019. Available from: <http://doi. org/10.1016/j.indcrop.2018.12.012>. Accessed: Apr. 06, 2021. doi: 10.1016/j.indcrop.2018.12.012.

NEKOEI, M.; MOHAMMADHOSSEINI, M. Chemical composition of the essential oils and volatiles of Salvia leriifolia by three different extraction methods prior to gas chromatographicmass spectrometric determination: Comparison of HD with SFME and HS-SPME. Journal of Essential Oil Bearing Plants, v.20, n.2, p.410-425, 2017. Available from: <https://doi.org/10.10 80/0972060X.2017.1305918>. Accessed: Apr. 06, 2021. doi: 10.1080/0972060X.2017.1305918.

NIST Chemistry, NIST Standard Reference Database Number 69 [CD-ROM], Gaithersburg (MD): National Institute of Standards and Technology, 2009 - CD-ROM.

OLIVEIRA, A. C. D.; ROPKE, C. D. Os dez anos da Política Nacional de Plantas Medicinais e Fitoterápicos (PNPMF) e os principais entraves da cadeia produtiva de extratos vegetais e medicamentos fitoterápicos no Brasil. Revista Fitos, v.10, n.2, p.95-219, 2016. Available from: <https://www.arca.fiocruz.br/ handle/icict/19253>. Accessed: Apr. 04, 2020. doi: 10.5935/24464775.20160015 .

PASSOS, G. F. et al. Anti-inflammatory and anti-allergic properties of the essential oil and active compounds from Cordia verbenacea. Journal of Ethnopharmacology, v.110, n.2, p.323-333, 2007. Available from: <https://doi.org/10.1016/j. jep.2006.09.032>. Accessed: Apr. 04, 2020. doi: 10.1016/j. jep.2006.09.032. 
QUEIROZ, T. B. et al. Content and chemical composition of the essential oil of 'erva-baleeira' (Varronia curassavica Jaqc.) as a function of harvesting times. Revista Brasileira de Plantas Medicinais, v.18, n.1, p.356-362, 2016. Available from: <www. cabdirect.org/cabdirect/abstract/20163195207>. Accessed: Feb. 08, 2020. doi: 10.1590/1983-084X/15_116.

RICHTER, J.; SCHELLENBERG, I. Comparison of different extraction methods for the determination of essential oils and related compounds from aromatic plants and optimization of solid-phase microextraction/gas chromatography. Analytical and Bioanalytical Chemistry, v.387, n.6, p.2207-2217, 2007. Available from: <https://ink.springer.com/article/10.1007/ s00216-006-1045-6>. Accessed: Apr. 04, 2020. doi: 10.1007/ s00216-006-1045-6.

RODRIGUES, F. F. et al. Chemical composition, antibacterial and antifungal activities of essential oil from Cordia verbenacea DC leaves. Pharmacognosy Research, v.4, n.3, p.161, 2012. Available from: <https://doi.org/10.1016/j.jep.2004.07.028>. Accessed: Feb. 08, 2020. doi: 10.1016/j.jep.2004.07.028.

RYAN, M. P. Patent incentives, technology markets, and publicprivate bio-medical innovation networks in Brazil. World Development, v.38, n.8, p.1082-1093, 2010. Available from: $<$ https://doi.org/10.1016/j.worlddev.2009.12.013>. Accessed: Apr. 04, 2020. doi: 10.1016/j.worlddev.2009.12.013.

SINGH, D. The relative importance of characters affecting genetic divergence. The Indian Journal of Genetic and Plant Breeding,

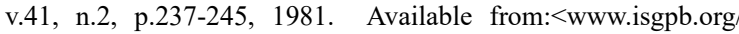
documents/archive/ijgpb-41-2-010.pdf>. Accessed: Jan. 20, 2020.

SNOW, N. H.; BULLOCK, G. P. Novel techniques for enhancing sensitivity in static headspace extraction-gas chromatography. Journal of Chromatography A, v.1217, n.16, p.2726-2735, 2010. Available from: <https://doi.org/10.1016/j.chroma.2010.01.005>. Accessed: Jan. 16, 2020. doi: 10.1016/j.chroma.2010.01.005.
SOUZA, V.C.; LORENZI, H. Botânica Sistemática: guia ilustrado para identificação das famílias de Fanerógamas nativas e exóticas no Brasil, baseado em APG III. Nova Odessa: Brasil, 2012.

SOUZA-MOREIRA, T. M. et al. Brazil in the context of plants and derivates quality control. Revista Brasileira de Farmacognosia, v.20, n.3, p.435-440, 2010. Available from: <https://doi. org/10.1590/S0102-695X2010000300023>. Accessed: Jan. 18, 2020. doi: 10.1590/S0102-695X2010000300023.

UBEDA, C. et al. Determination of major volatile compounds during the production of fruit vinegars by static headspace gas chromatography-mass spectrometry method. Food Research International, v.44, n.1, p.259-268, 2011. Available from: $<$ https:// doi.org/10.1016/j.foodres.2010.10.025>. Accessed: Apr. 04, 2020. doi: 10.1016/j.foodres.2010.10.025.

VAN DEN DOOL, H.; KRATZ, P. A generalization of the retention index system including linear temperature programmed gasliquid partition chromatography. Journal of Chromatography, v.11, p.463-471, 1963. Available from: <https://worldveg.tind. io/record/1766/>. Accessed: Apr. 04, 2020. doi.: 10.1016/S00219673(01)80947-X.

WANG, X. et al. Study on the Difference between Volatile Constituents of the Different Parts from Elsholtzia ciliata by SHS-GCMS. American Journal of Analytical Chemistry, v.8, n.10, p.625, 2017. Available from: <https://doi.org/10.4236/ajac.2017.810045>. Accessed: Jan. 18, 2020. doi: 10.4236/ajac.2017.810045.

ZANOUSI, M. B. P. et al. Composition of the essential oils and volatile fractions of Artemisia absinthium by three different extraction methods: Hydrodistillation, solvent-free microwave extraction and headspace solid-phase microextraction combined with a novel QSRR evaluation. Journal of Essential Oil Bearing Plants, v.19, n.7, p.1561-1581, 2016. Available from: <https:// doi.org/10.1080/0972060X.2014.1001139>. Apr. 06, 2021. doi: 10.1080/0972060X.2014.1001139. 